\title{
The importance of buildings with base-to-ridge posts in Mexico in the global history of architecture
}

\author{
E. Koshi \& T. Tsuchimoto \\ Shinshu University, Japan
}

\begin{abstract}
Munamochibashira (base-to-ridge-posts) are posts that rise from the ground to directly support the ridge. They are an important object of study in examining the origin, transformation, and spread of an architectural culture. It is already known that buildings with base-to-ridge-posts exist in vernacular architecture from research in Asia and Europe, but this type of building in Central America has not been discussed in previous studies. In 2013, we conducted a field study in Central America and observed this type of building. In Mexico, we frequently found buildings with base-to-ridge-posts in vernacular architecture. Moreover, we found buildings of this type: 1) among wooden buildings designated as UNESCO's World Heritage Sites on the American continent; 2) in villages around Tapalpa, about $120 \mathrm{~km}$ from Guadalajara; and 3) in academic books and research reports in Spanish that we obtained in Mexico and reports in Spanish or English collected afterwards.

In this paper, we report the findings of our field and literature studies concerning buildings with base-to-ridge-posts among structures made by the indigenous people of Mexico. We will also demonstrate that the origin of buildings with base-to-ridge-posts on the American continents could be Asia or Europe. Since we directly observed buildings with base-to-ridge-posts in Mexico and established that there are base-to-ridge-post styles of architecture on the American continents, we claim that the continents are part of cultural areas that have buildings with base-to-ridge posts. Consequently, we maintain that Central America is a highly important field of study in investigating the history of buildings with base-to-ridge-posts from the prehistoric era on a worldwide scale. Keywords: Mexico, munamochibashira (base-to-ridge posts), Indio, continents, transmission and culture, origin.
\end{abstract}




\section{Introduction}

The International Wood Committee held a conference in Guadalajara, Jalisco, the mid-western part of the central plateau in Mexico, November 14-16, 2012. The committee was one of the international committees in ICOMOS (the International Council on Monuments and Sites) that organized academic studies on wooden architecture worldwide. We will show some knowledge of buildings with munamochibashira (base-to-ridge-posts) that we obtained at this conference and from our research.

First, during the conference, we found relics of buildings with base-to-ridge posts in the posters of wooden structures registered as world heritage sites, which were produced chiefly by G. Tampone, Chairperson of the committee. Second, we directly observed some buildings with base-to-ridge posts when we visited villages in and around Tapalpa, about $120 \mathrm{~km}$ from Guadalajara, as part of an inspection tour organized by the secretariat of the host country after the conference on November 17, 2012. Third, we identified buildings with base-to-ridge posts in the academic materials and research reports in Spanish obtained in Mexico and in the academic materials and research reports in Spanish or English that we collected after the conference.

We will report the result of our field and literature research regarding buildings with base-to-ridge posts built and used by the indigenous people of Mexico. The phrase "base-to-ridge posts" means posts that rise from the ground to directly support the ridge and the phrase "buildings with base-to-ridge posts" means buildings that have at least one base-to-ridge post.

It has been increasingly accepted in previous studies that the base-to-ridge post structure is a prototype in the history of architecture. In addition, the origin of buildings with base-to-ridge posts on the American continents can be either or both Asia and Europe. Based on these understandings, this paper will examine the distribution of buildings with base-to-ridge posts on the American continents and will offer the total picture of the lineal transmission of this style of architecture. There are not many academic sources that focus on our topic, but we will refer to work by Watanabe [1], Asakawa [2], and Ota [3] as a few of our predecessors.

Studies on buildings with base-to-ridge posts have been conducted with respect to the separate geographical areas by Asakawa [2] and Li and Tsuchimoto [4] in China; Wakabayashi [5] and Asakawa [2] in Southeast Asia; Watanabe [1] in North America; Koshi and Tsuchimoto [6] in Central America; Tsuchimoto [7] in Japan; Ota [3] and Tsuchimoto [8] in Europe; Umesao [9] in Africa; and May [10] in Oceania. These studies have verified that buildings with base-to-ridge posts exist in different parts of the world. However, not much is known about how they became so widespread. Ota [3] points out that systematic studies are lacking with regard to Africa and America.

In this academic context, we confirmed that there were buildings with base-toridge posts in Central America by conducting a field study in Mexico, Guatemala, and Belize in June 2013. This is a significant finding for the investigation of the transmission of architectural style with base-to-ridge posts. 


\section{Building with base-to-ridge posts in Mexico and its surrounding areas}

\subsection{Buildings with base-to-ridge posts found in wooden World Heritage structures}

Among the wooden buildings designated as UNESCO's World Heritage Sites on the American continents are the L'Anse aux Meadows National Historic Site in Canada (Figure 1), SGang Gwaay in Canada (Figure 2), and the Joya de Cerén Archaeological Site in El Salvador (Figure 3). Figures 1 to 3 are photos taken from the posters made by Chairperson G. Tampone.

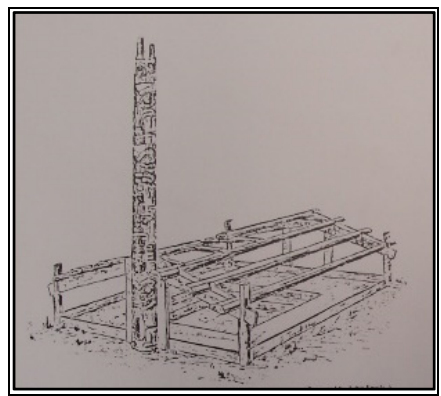

Figure 1: The L'Anse aux Meadows National Historic Site (Canada).

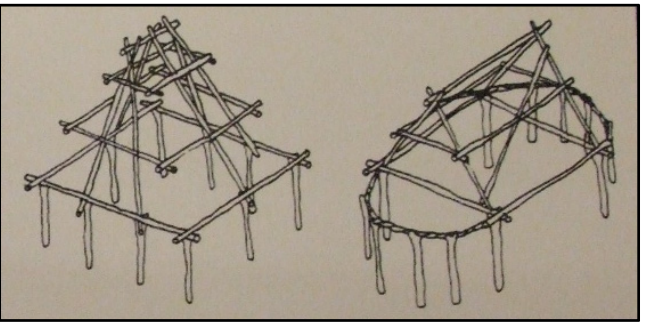

Figure 3: The Joya de Cerén Archaeological Site (El Salvador).

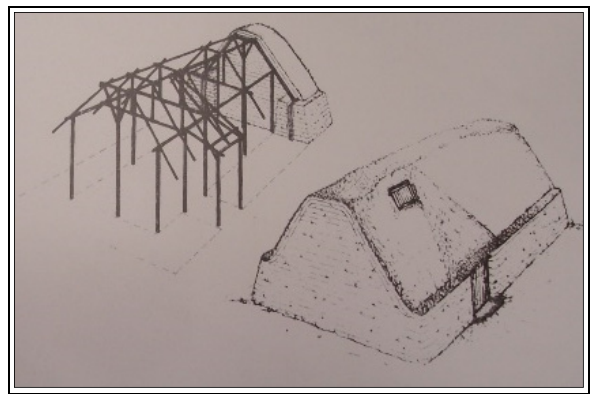

Figure 2: SGang Gwaay (Canada).

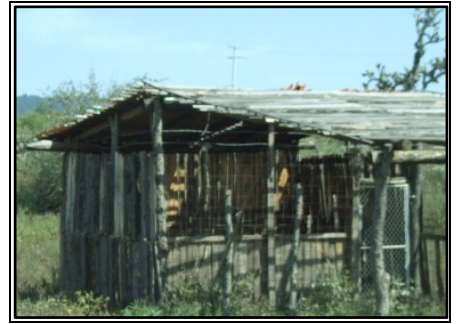

Figure 4: Buildings with baseto-ridge posts around Tapalpa 1, Mexico (photo taken by the authors).

\subsection{Buildings with base-to-ridge posts observed in the inspection tour}

In the inspection tour to and around Tapalpa, we observed houses and sheds that commonly had base-to-ridge posts and that those structures were scattered throughout the area. Figures 4 to 6 show some of the sheds seen in the villages. 
We observed that most of the structures in the villages had base-to-ridge posts, regardless of whether wooden or otherwise. Based on these observations, we can reasonably expect that buildings in the adjacent areas also had the same style with base-to-ridge posts.

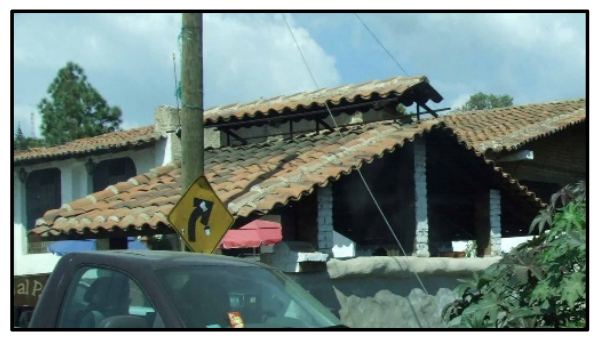

Figure 5: Buildings with base-to-ridge posts around Tapalpa 2, Mexico (photo by the authors).

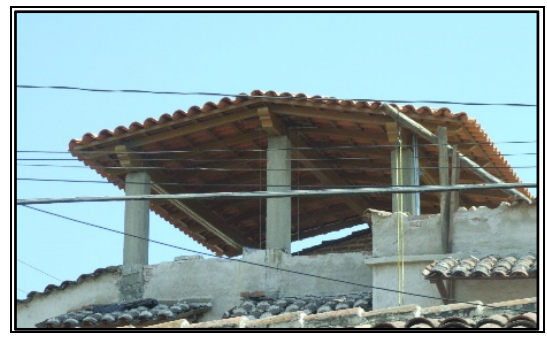

Figure 6: Buildings with base-toridge posts around Tapalpa 3, Mexico (photo by the authors).

\subsection{Buildings with base-to-ridge posts identified in literature}

We will show some of the buildings with base-to-ridge posts on the American continents that appear in academic publications and research reports. There are three types as presented: (1) buildings with base-to-ridge posts recorded in old photographs (Figure 7); (2) those that are recorded in drawings based on measurements (Figure 8); and (3) those pictured in drawings as estimated reconstructions (Figure 9).

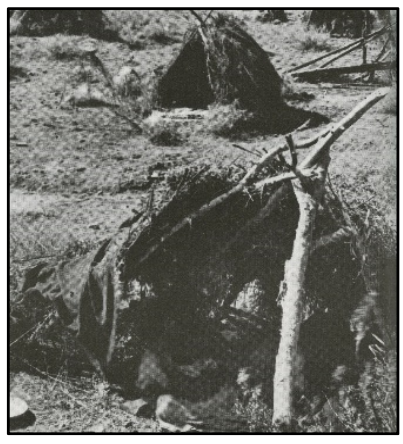

Figure 7: Desert Dwellers (Josephy [11], Beatriz [12]).

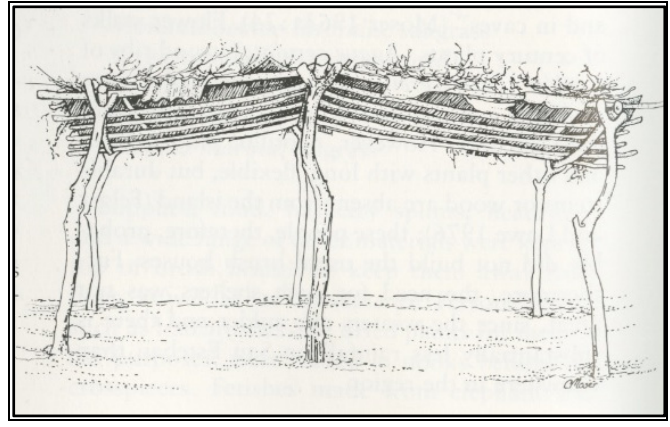

Figure 8: Traditional Ramada (Beatriz [12], Felger [13]). 


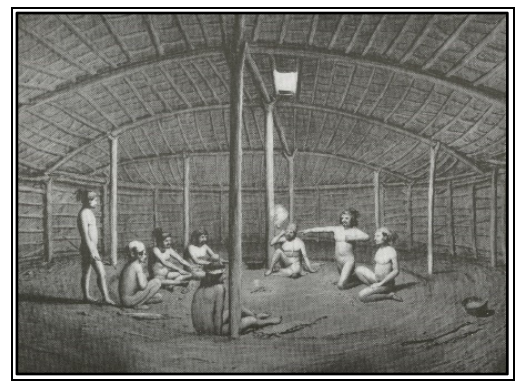

Figure 9: California Indians (Josephy [11]).

\section{Considerations of building with base-to-ridge posts on the American continents}

\subsection{Possibility of Asian origin}

Generally two scenarios explain how the architectural style with base-to-ridge posts was transmitted to the American continents. One is that the architecture technology of hunting people in Asia was brought to the American continents through migration; the other explanation is that the hunting people did not have the technology but developed it after they migrated from Asia to the American continents, crossing ice-bound Beringia.

\subsection{Possibility of European origin}

The possible European origin of buildings with base-to-ridge posts is much later than the possible Asian origin. It is nonetheless reasonable to assume that, after the discovery of the continents by Columbus, migrants from Europe to the new continents built dwellings without help from architectural artisans. Since it has been reported that there are the relics of buildings with base-to-ridge posts in Europe (Switzerland, Germany, Austria, Italy, France, Denmark, and so on), the possibility is that there were buildings with base-to-ridge posts on the American continents of European origin. That said, as far as we have researched, buildings with base-to-ridge posts have not been found in Spain and Portugal at present.

\section{Distribution of building with base-to-ridge posts and their lineal transmissions}

\subsection{Possible origins of buildings with base-to-ridge posts in the Japanese Archipelago}

There are two possibilities for the origin of buildings with base-to-ridge posts in Japan: (1) they might have originated from traditional Japanese buildings, such as the Ise Jingu Shrine or private houses; and (2) since Japan is located just east of Eurasia, the temple architecture introduced from China might be the origin. 


\subsection{Transmission of the style between continents}

As for the transmission of the style of architecture with base-to-ridge posts along the Pacific Rim, it is reasonable to hypothesize that the style was transmitted from Eurasia (the older continent) to the American continents (the newer continents) (Figure 10).

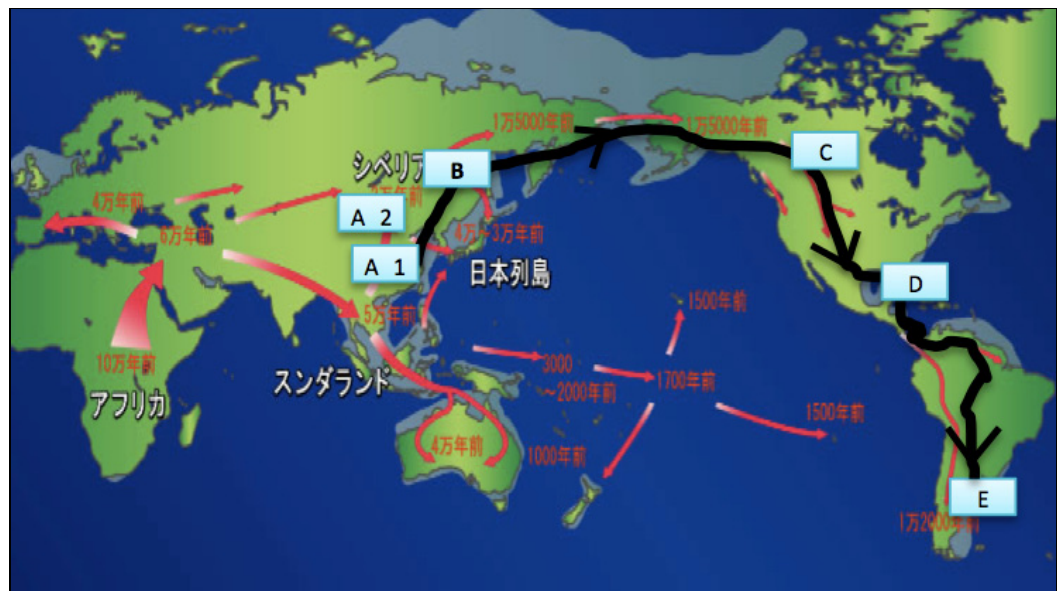

Figure 10: Distribution of buildings with base-to-ridge posts and their lineal transmissions（国立科学博物館 National Museum of Nature and Science, Tokyo).

In China, there are two different lineages - the northern and southern areas, respectively: the raised-floor style in the southern area, and the pit style in the northern area. It is widely considered that the main route of expansion of the baseto-ridge posts style to the American continents is from the northern area of China, where the pit style was dominant, towards the north, across the eastern end of Eurasia. Still, there is also a possibility that the raised-floor style that was common in houses in the southern area was transmitted to those continents. The pit-style architecture in northern China, where the temperature difference is significant, developed later into the post-and-lintel construction with base-to-ridge posts. Raised-floor style buildings are not found in northern China, but they are found in the northeastern part of Eurasia where hunter-gatherers used them as storehouses. There are buildings with base-to-ridge posts among the architectural remains of raised-floor style structures in southern China. Whereas, in northern China, buildings with base-to-ridge posts started to develop when wooden posts were added to pit-style houses. Further north, in the northeastern part of Eurasia, both the pit-style houses with base-to-ridge posts and raised-floor style houses have been found. From these factors, it is possible to build the scenario that two different architectural traditions in northern and southern China, both of which had base-toridge posts, coexisted and then together expanded from Eurasia to the American continents. 


\subsection{Perspective to the north}

In the research on buildings with base-to-ridge posts, the main subjects have been buildings in areas south from Japan, such as Southeast Asia, Taiwan, the South Seas, and southern China. The significance of paying more attention to the northeastern part of Eurasia was pointed out by Watanabe [1] and Asakawa [2]. In particular, Watanabe focuses on northern Eurasia and the northern part of North America and offers some noteworthy viewpoints in his “狩猟採集民の住居一北 方からの視点 (“Houses of hunter-gatherer; Viewpoints from the north”) [1]. As part of the unique perspective from observations of the culture of hunter-gatherers in those northern areas, Watanabe claimed that northern hunter-gatherers developed an architecture with solid wooden frames that are remarkably different from the style of architecture developed by hunter-gatherers in the southern tropic areas. The factors he considered important in examining the origin of the style of dwelling architecture include base-to-ridge posts, religions and rituals, hearth, storehouse, birth huts, sweat huts, and cooking huts. Needless to say, Watanabe's attention to base-to-ridge posts makes his work immediately relevant to my topic.

Furthermore, Watanabe showed the framework of the Nootka winter house, since the Nootka is a good representative of hunter-gatherers in the southern part of the Northwest Pacific Coast of North America. Also, he refers to the Tsimshian smokehouse for processing and drying salmon and trout as an example of huntergatherers living further north than the Nootka. In addition, as a Asian part after discussing the Chishima Ainu, Watanabe shows a photograph of a log cabin (under construction) being built by the Ul'chi, who are hunter-fishermen of the Lower Amur River.

Watanabe asserts in his conclusion to the paper that although research on the origin of Japanese has tended to focus on southern areas that are far away over the seas, if we are to be scientific, we need to remove such a bias and, as has already been done in historiography, to pay more careful attention to nearby areas and peoples, such as those in the northern areas. Watanabe's claims are important in the context of the history of architecture in the sense that they can show the connection between architecture in Eurasia and on the American continents. We think that we can obtain significant findings in our field of research by verifying constructively the details of Watanabe's views.

In addition, Li and Tsuchimoto's work [4] clarified that there are quite a few buildings with base-to-ridge posts among the traditional post-and-lintel style wooden structures in certain areas in northern China, such as the middle and lower Yellow River. That said, as well as buildings in northern China, we should also consider raised-floor style houses with base-to-ridge posts in southern China as the origin of the systematic expansion of buildings with base-to-ridge posts. For, as mentioned above, there is a possibility that more than one civilization with a base-to-ridge posts style of architecture expanded onto the American continents via the northeastern part of Eurasia (Figure 11). 


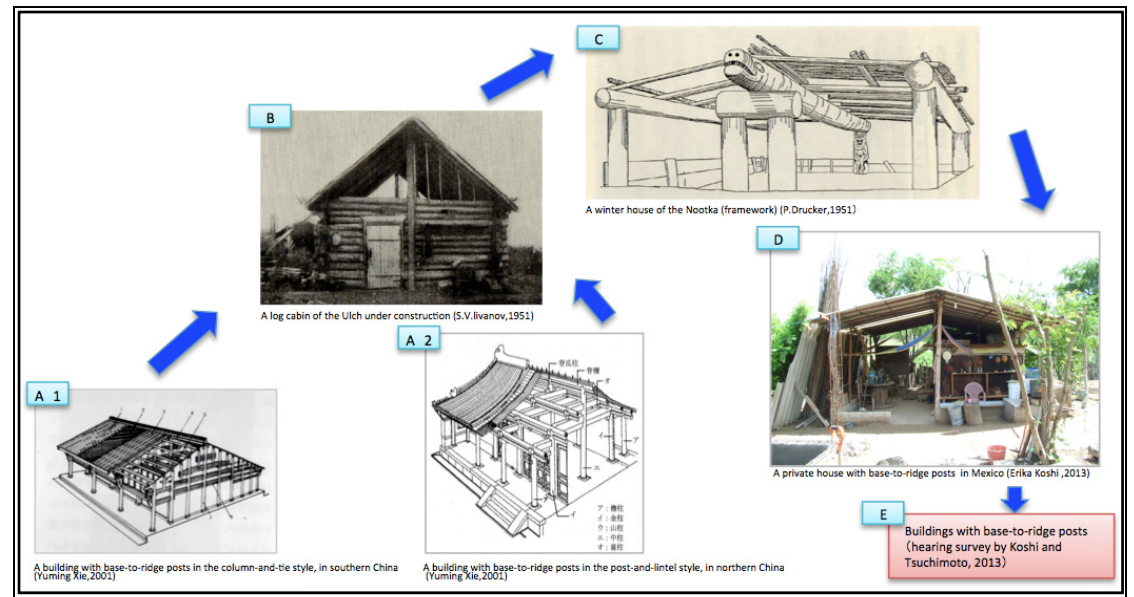

Figure 11: Lineal transmission of the architectural style with base-to-ridge posts by land from Eurasia (the "old" continent) to the American continents (the "new" continents). A1: a building with base-to-ridge posts in the column-and-tie style, in southern China (Xie [14]); A2: building with base-to-ridge posts in the post-and-lintel style, in Northern China (Xie [14]); B: a log cabin of the Ul'chi (under construction) (Ivanov [15]); C: a winter house of the Nootka framework) (Drucker [16]); D: a private house with base-to-ridge posts in Mexico (by the authors); E: buildings with base-to-ridge posts in Argentina (hearing survey by the authors 2013).

\subsection{Buildings with base-to-ridge posts in Central America}

We conducted measuring and interview surveys for fifteen days in Mexico and neighboring areas in Central America from June 5 to 19 in 2013. On the American continents, structures with base-to-ridge posts are still being built and used in Central America, such as Mexico, Guatemala, and Belize (Figures 12-16). This survey examined the current conditions and construction process of relatively small buildings with base-to-ridge posts. We also found how the constructors were involved in the construction work. We found 41 buildings with base-to-ridge posts, conducted a measuring survey on 24 of them, and an interview survey on 21 . As a result of the interview survey, we found the current situation of the buildings as follows:

1. Use of the buildings:

- 12 of them are huts, such as work huts

- 6 of them are shops

- 3 of them are dwellings

2. The constructor:

o the owner is the constructor of 17 of them

- a professional carpenter is the constructor of 4 of them 
3. The roof material:

- 11 of them are tin-roofed

- 3 of them are unknown (under construction)

- 2 of them are roofed with leaves (of a Palmae plant)

- 2 of them are roofed with vinyl

- 2 of them are roofed with tiles

- 1 of them is not roofed

4. The scale of the building:

o the smallest building: $3000 \mathrm{~mm} \times 3100 \mathrm{~mm}$

○ the largest building: $8000 \mathrm{~mm} \times 3600 \mathrm{~mm}$

5. The construction date:

o the oldest building: built in 1953

o the newest building: the ones under construction

○ the number of buildings built in and after 2000: 12

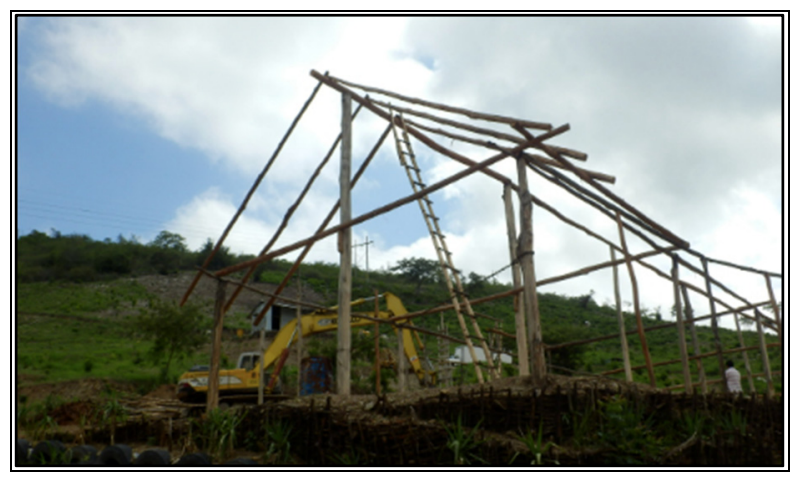

Figure 12: A structure with base-to-ridge posts in Agua Salobrega, Guatemala (photo by the authors).

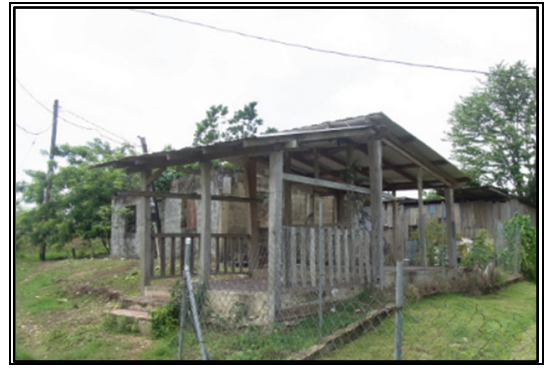

Figure 13: A structure with base-toridge posts in Cotton Tree, Belize (photo by the authors).

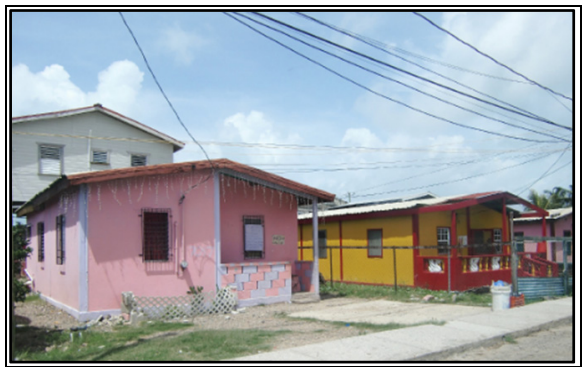

Figure 14: Structures with base-to-ridge posts in Belize City, Belize (photo by the authors). 


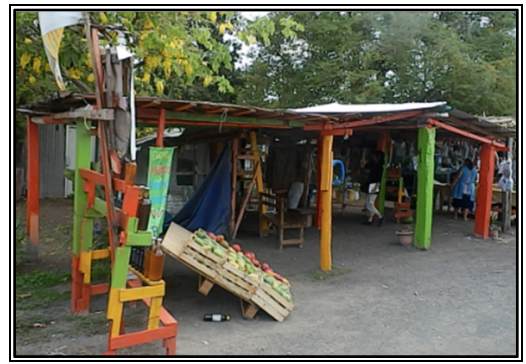

Figure 15: A structure with baseto-ridge posts in Xalapa, Mexico (photo by the authors).

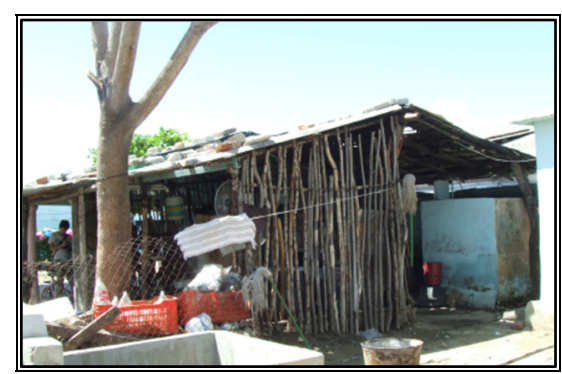

Figure 16: A structure with base-toridge posts in Paredón, Mexico (photo by the authors).

The buildings with base-to-ridge posts that we observed in Mexico had very simple structures with logs. Some of them were with hottatebashira (earth-fast posts) or with a thatched roof. It should be noted that they have the complete structure of the base-to-ridge posts style, despite the simplicity as buildings.

In addition, from the interview survey, we found a number of cases in which the owner of the property built the structure in cooperation with other people. It appears plausible that in Central America, the technology of the base-to-ridge posts style architecture was transmitted through cooperative construction in the neighboring areas. There was even a case in which one person just saw a building with base-to-ridge posts, understood the structure, and actually built a structure in the same style. This suggests that buildings with base-to-ridge posts have the characteristic that their structure is easy to replicate by watching, and because of that, they are expanding even now. Moreover, further south on the South American continent, we know from reports that there is a building in Argentina with baseto-ridge posts. The buildings with base-to-ridge posts in Mexico are especially significant considering that Mexico is located along the transmission route from the northeastern part of Eurasia to the southernmost area of the South American continent.

\section{Conclusions}

Thus, based on the observations of concrete examples in our fieldwork in Mexico, we obtained an overview of the status of buildings with base-to-ridge posts among the structures on the American continents. The American continents are part of the cultural areas that have buildings with base-to-ridge posts. Mexico, located in the center of the American continents, is a very important area for research into the history of buildings with base-to-ridge posts in the wider context that includes intercontinental expansion and development from the prehistoric era.

Buildings with base-to-ridge posts are a widely shared feature in the development of wooden architecture in different areas. Because of this, we can learn more about the connections and relationships between civilizations by 
searching for the origin of architecture with base-to-ridge posts and by investigating the systematic development and transmission on each continent. Buildings with base-to-ridge posts are a primitive type of architecture that has been developed and used worldwide. By researching how buildings of this kind are developed in different areas of the world, we can comprehend the history of civilizations connecting the old and new continents in the form of the history of architecture.

We have also shown that, at present, there are three possibilities for the main origin of buildings with base-to-ridge posts in Mexico: (1) the raised-floor style buildings in the southern area of Eurasia; (2) the pit style buildings from the northern area of Eurasia, and (3) structures built by migrants from Europe after Columbus. Each of these is plausible and should not be discarded. This is to say, at present we cannot decisively choose one origin as the only possible one for the systematic transmission of the base-to-ridge posts style. If it is about the origin of modern humans, Africa is widely accepted as the starting point, and indeed, there are buildings with base-to-ridge posts in Africa. From this, it can be inferred that modern humans started in Africa, then moved to Europe and Asia, and after that, exchanges between different civilizations occurred. The transmission of the baseto-ridge posts style can be considered part of this mass movement. Also, at the time of the discovery of the new continents, transmission was still possible and the base-to-ridge-posts style of architecture might have been brought into by European settlers.

The fact that buildings with base-to-ridge posts exist on the Eurasian continent, the North and South American continents, the African continent, and Oceania indicates that their transmission was by land and sea.

Watanabe [1] mentioned the presence of the base-to-ridge posts style in northern Asia, Canada, and America. Based on our fieldwork in Mexico, Guatemala, and Belize in 2013, we showed that buildings with base-to-ridge posts spread as far as Argentina, the southern end of the migration of humans. In Mexico especially, buildings with base-to-ridge posts are observed in a number of different places and materials, including some buildings designated as UNESCO's World Heritage Sites, the ones we directly observed in our fieldwork, and those that we confirmed in the relevant literature. Hence, Mexico, located along the transmission route of civilizations, is highly significant as a field of research for our investigation of buildings with base-to-ridge posts.

\section{References}

[1] Watanabe, H. 渡辺仁. Houses of hunter-gatherer; Viewpoints from the north 狩猟採集民の住居一北方からの視点, 日本のすまいの源流一 日本基層文化の探求 (Origin of the houses of Japan; A study on cultural prototype of Japan), 文化出版局 (Bunka Publishing Bureau): 東京 (Tokyo), pp. 389-417, 1984.

[2] Asakawa, S. 浅川滋男. 南方と北方のクラ(7 章) (Southern and northern storehouse (Chapter 7), 先史日本の住居とその周辺 (Prehistoric Japan 
794 Structural Studies, Repairs and Maintenance of Heritage Architecture XIV

of houses and its surrounding), 浅川滋男編(ed. Asakawa, S.), 同成社 (Douseisha): 東京 (Tokyo), pp. 379-419, 1998.

[3] Ota, K. 太田邦夫, エスノ・アーキテクチュア (Ethno-architecture), 鹿島出版会 (Kajima Institute Publishing Co.): 東京 (Tokyo), 2010.

[4] Li, Y. \& Tsuchimoto, T. 李雅濱・土本俊和, 中国北部地域にみる伝統 的大木技術における棟持柱を持つ抬梁式構造 (Study on MunamochiBashira of Post-and-Lintel construction in the traditional structures of northern China), 日本建築学会計画系論文集 (Journal of architecture and planning), vol. 78, No. 688, pp. 1399-1408, 2013.

[5] Wakabayashi, H. 若林宏子, 高床式建物の源流 (Origin of the floor elevated buildings), 弘文堂 (Koubundo Publishers Inc.): 東京 (Tokyo), 1986.

[6] Koshi, E. \& Tsuchimoto, T. 輿恵理香・土本俊和, メキシコの棟持柱建 築 (On Buildings with base-to-ridge posts in Mexico), 日本建築学会学術 講演梗概集 (北海道) (Summaries of technical papers of annual meeting Architectural Institute of Japan (Hokkaido)), No. 9007, pp. 13-14, 2013.

[7] Tsuchimoto, T. 土本俊和, 棟持柱祖形論 (Original Form Theory on Ridge Supporting-Post), 中央公論美術出版 (Chuo Kouron Bijutsu Shuppan Shuppan): 東京 (Tokyo), 2011.

[8] Tsuchimoto, T., Some similarities on the making of the timber-framed structures in Europe and Japan, 20-24 June 2010, WCTE (World Conference on Timber Engineering) 2010 Proceedings, University of Trento, Riva del Garda, Italy.

[9] Umesao, T. 梅棹忠夫，ダトーガ族の住居 (4-2章) (Housing of the Datoga (Chapter 4-2), アフリカ社会の研究 京都大学アフリカ学術調查隊報告 (Studies in African Society; Report of the Kyoto University Africa Scientific Expedition), 今西錦司・梅棹忠夫編 (ed. Imanishi, K. \& Umesao, T.), 西村書店 (Nishimura-Shyoten): 東京 (Tokyo), pp. 173-180, 1968.

[10] May, J., Building without architects, Rizzoli: New York, 2010.

[11] Josephy, A. M. Jr., The American Heritage Book of INDIANS, American Heritage: New York, 1982.

[12] Beatriz, B. C., La arquitectura de Mesoamerica y de la Gran Chichimeca (The architecture of Mesoamerica and the Gran Chichimeca), Instituto Nacional de Antropologia e Histria(National Institute of Anthropology and Histria): México, D. F. (Mexico City), 2010.

[13] Felger, R. S., People of the desert and sea, The University of Arizona press: Tucson, 1985.

[14] Xie，Y. 謝玉明，中国伝統建築細部設計(Detail design on traditional architecture of China), 中国建築工業出版社, (China architecture \& building press): 北京 (Beijing), 2001.

[15] Ivanov, S. V., Старинное зимнее жилище ульчей (Ancient Winter House of Ul'chi) Главе 2 (Chapter 2). Сборник Музея антропологии $u$ 
этнографии том 13 (Collection of the Museum of Anthropology and Ethnography Volume 13), Институт этнографии им. Н.Н. МиклухоМаклая АН CCCP (Institute of Ethnography. NN Maclay USSR Academy of Sciences): Москва (Moscow), p. 84, 1951.

[16] Drucker, P., The Northern and Central Nootkon Tribes, Smithsonian Institution Bureau of American Ethnology Bulletin 144: Washington D.C. 25, p. $68,1951$.

[17] Francisco, G. R., Arquitectura varnacula del sotavento (Varnacular Architecture of Leeward), Consejo Nacional para la Cultura y las Artes (National Council for Culture and Arts): México, D. F. (Mexico City), 2010. 